\title{
Seasonal Movements and Relative Abundance of Bearded Seals (Erignathus barbatus) in the Coastal Waters of the Chukotka Peninsula
}

\author{
Vladimir V. Melnikov ${ }^{1}$
}

(Received 29 November 2016; accepted in revised form 16 June 2016)

\begin{abstract}
Information about bearded seal seasonal distribution in the Pacific Arctic is limited. Bearded seals (Erignathus barbatus Exleben, 1777) from coastal sites along the southern, eastern, and northern Chukotka Peninsula, Russian Federation, were observed most seasons during 1993-96, 1998-2000, 2002-05, and 2010-11. These observations provide spatial and temporal information about bearded seal seasonal distribution, movements, and relative numbers in the coastal zones. In winter, bearded seals aggregate on the young ice in the northern part of the Gulf of Anadyr. Numbers gradually increase during March. In springtime (April-May), bearded seals in the northern Gulf of Anadyr are relatively numerous around Nunligran (Cape Achen), but the number is highly variable across years. During spring bearded seals move eastward along the coast from the northern part of the Gulf of Anadyr towards the Bering Strait and then to the north, as the marginal ice edge zone retreats north. These movements to the east and north continue in ice-free water, and by August, the spring migration of bearded seals along the coast of the Chukotka Peninsula ends. In the summer months of August and September, few bearded seals are present in this coastal zone. The southward autumn migration of bearded seals is not evident near the coast, which suggests that it occurs farther from shore.
\end{abstract}

Key words: bearded seal; shore-based visual observations; Chukotka Peninsula; Gulf of Anadyr; Chukchi Sea; migration

RÉSUMÉ. Il existe peu de renseignements sur la distribution saisonnière du phoque barbu dans le secteur pacifique de l'Arctique. Des phoques barbus (Erignathus barbatus Exleben, 1777) ont été observés sur divers sites côtiers tout au long du sud, de l'est et du nord de la péninsule de Tchoukotcha, Fédération de Russie, pendant les années 1993-1996, 1998-2000, 2002-2005 et 2010-2011. Ces observations permettent d'obtenir des données spatiales et temporelles au sujet de la distribution saisonnière et des déplacements du phoque barbu, ainsi qu'au sujet du nombre relatif de phoques barbus dans les zones côtières. L'hiver, les phoques barbus se rassemblent sur la jeune glace de la partie nord du golfe de l'Anadyr. Le nombre de phoques augmente graduellement au mois de mars. Au printemps (avril-mai), les phoques barbus du nord du golfe de l'Anadyr sont relativement nombreux dans les environs de Nunligran (cap Achen), mais leurs nombres varient beaucoup d'une année à l'autre. Pendant le printemps, les phoques barbus se déplacent vers l'est, le long de la côte, depuis la partie nord du golfe de l'Anadyr vers le détroit de Béring, puis vers le nord lorsque la zone marginale des lisières de glace recule vers le nord. Ces déplacements en direction est et en direction nord se poursuivent en eaux libres, et vers le mois d'août, la migration printanière des phoques barbus le long de la côte de la péninsule de Tchoukotcha prend fin. Pendant les mois d'été d'août et de septembre, les phoques barbus se font rares dans cette zone côtière. La migration automnale vers le sud des phoques barbus n'est pas évidente près de la côte, ce qui suggère qu'elle se produit loin de la rive.

Mots clés : phoque barbu; observations visuelles à partir de la côte; péninsule de Tchoukotcha; golfe de l'Anadyr; mer des Tchouktches; migration

Traduit pour la revue Arctic par Nicole Giguère.

АБСТРАКТ. Информация о сезонном распределении лахтака в тихоокеанском секторе Арктики ограничена. Исследования лахтака (Erignathus barbatus Exleben, 1777) проводили с береговых наблюдательных пунктов расположенных на южном, восточном и северном побережье Чукотского полуострова Российской Федерации в 1993-96, 1998-2000, 2002-05 и в 2010-11 гг. В результате была получена информация о пространственном, временном, сезонном распределении, перемещениях и относительной численности лахтака в прибрежной зоне Чукотки. В зимний период лахтак образует агрегации на молодом льду в северной части Анадырского залива, где его численность постепенно возрастает на протяжении марта. Весной (апрель -май) в северной части Анадырского залива лахтак наиболее многочислен в районе пос. Нунлигран (мыс Аччен), однако его численность в этом районе в межгодовом отношении очень вариабельна. В весенний период лахтаки движутся на восток вдоль побережья северной части Анадырского залива, вдоль восточного побережья Чукотки в направлении Берингова пролива, а

${ }^{1}$ V.I. Il'ichev Pacific Oceanological Institute (POI), 43 Baltiyskaya Street, Vladivostok, 690041, Russia; vmelnikov@poi.dvo.ru (C) The Arctic Institute of North America 
затем на север по мере перемещения на север кромки дрейфующего льда. Это движение на восток и север вдоль побережья Чукотского полуострова продолжается по свободной ото льда воде и заканчивается к августу. В летние месяцы встречи лахтака в прибрежье Чукотского полуострова единичны. Осенняя миграция лахтака на юг в прибрежье Чукотки выражена слабо, что указывает на его движение вдали от берегов.

Ключевые слова: лахтак, береговые наблюдения, Чукотский полуостров, Анадырский залив, Чукотское море, миграции

\section{INTRODUCTION}

The bearded seal (Erignathus barbatus) is the largest of the northern Pacific Ocean seals in the family Phocidae, first described by Gray in 1825 . These seals have a widespread circumpolar distribution and are associated with seasonal sea ice in the shallow Arctic seas (Heptner et al., 1976; Burns et al., 1981). They are common inhabitants of the coastal waters surrounding the Chukotka Peninsula, including areas of the Bering and Chukchi Seas. Information about bearded seal seasonal distribution in the Pacific Arctic is limited. Bearded seals are generally considered to be inhabitants of sparse drifting ice with polynyas and fractures, which are characteristic of the Bering Sea. When given the opportunity, bearded seals prefer to use natural openings in the ice, such as polynyas and cracks, to breathe and access the ice surface. Breathing holes and lairs are used infrequently. However, these animals will make and maintain breathing holes if necessary (Rutilevsky, 1939; Burns and Frost, 1979).

On the basis of studies in the Okhotsk and Bering Seas, most bearded seals were believed to remain in the drifting ice of the Bering Sea, shifting with the ice to the south in winter and to the north in spring (Heptner et al., 1976). It was assumed that a passive drift of animals occurred from the southern regions to the north and that when ice in the Bering Sea disappeared, the bearded seals moved toward the coast (Fedoseev et al., 1988). According to Kosygin (1966), the increase from April to May in the number of bearded seals hauled out on the ice might be explained by the migration of bearded seals from the eastern part of the Bering Sea. Increasing evidence suggests an active spring migration of some bearded seals from the south through the Bering Strait to the north to summering areas near the ice edge in the Chukchi Sea (Burns and Frost, 1979; Cameron et al., 2010). Other bearded seals, however, remain in the ice-free areas of the Bering and Chukchi Seas (Burns et al., 1981; Fedoseev et al., 1988).

Despite the great importance of bearded seals as a food source for the Native peoples of the North, research on bearded seals halted in Russia after commercial pelagic marine mammal hunting ended. The primary purpose of this study is to examine the seasonal movements and relative abundance of bearded seals in the coastal waters surrounding the Chukotka Peninsula. The study is based on observations of marine mammals from both shorebased observation posts and boats between 1994 and 2011 (Melnikov and Bobkov, 1993; Melnikov et al., 2007; Melnikov, 2014).

\section{METHODS}

Observation of bearded seals was conducted concurrently with observation of other marine mammal species. In some years, up to 30 Native Chukotkan observers were employed at this task, though only one or two observers were involved in the beginning and at the end of the work. Some watched from observation posts in Native villages on shore, and others from motorboats during hunting trips to obtain marine mammals for food and other needs of the Native population (Fig. 1, Table 1). Observations were conducted mainly from April through November, but in some years the seals were observed year-round.

Visual observations were made with binoculars, with observers taking note of elevation of the observation perch, duration of observations, observation conditions (direction and force of wind, visibility, presence or absence of whitecaps), percent ice cover, number of marine mammals sighted, their approximate distance from shore, and their swim direction.

In the course of the observations, the hunters employed on the project gained experience, which was evident in their improved performance. Organization also improved as work progressed. The most extensive research efforts occurred in 1994-96, and then in 2000, 2002-03, and 2005 (Table 1). The relative lack of data collected in 1993 was due basically to the lack of experience of the observers, while poor organization was responsible for the lack of data in 1997 and scanty information for 1998.

Recording the length of time an observer conducted observations on any particular day turned out to be a difficult organizational issue. It would take only $30 \mathrm{~min}$ of actual observation time to determine the number of animals in the sector of observation and what species they were, yet most of the observers working in the villages listed the duration of observations as the length of the working day. Such reports obviously bore little relation to reality, since observations were conducted sporadically. But it must also be borne in mind that a hunter's own observations are always augmented by information received from other people in the village looking out to sea. For these reasons, observers found it hard to decide on observation time: some recorded the time spent looking through binoculars; others, the time spent on the shore; and still others, the length of the working day. Observers sitting in a boat during a hunting expedition may have been hampered by a low vantage point that limited their field of vision, but on the other hand, they were constantly on the move, and all members of the crew 


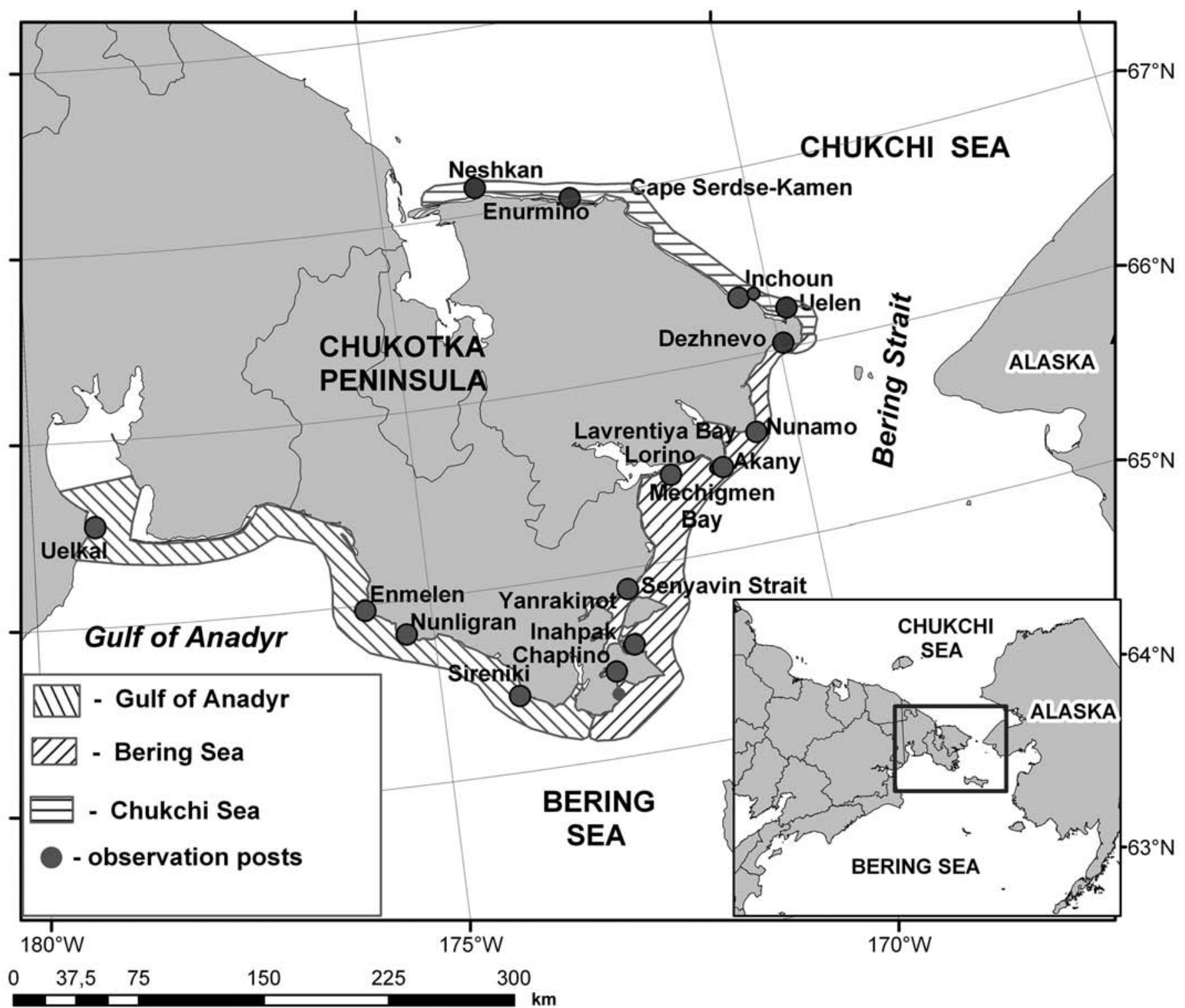

FIG. 1. Study area. Locations of observation posts along the Chukotka coast from which bearded seals were observed. The names on the map represent all base observation posts, but the data obtained from individual observation points were analyzed by area: Gulf of Anadyr, Bering Sea, Chukchi Sea.

watched out for marine mammals, often from dawn till dark. However, they recorded information in the logbook only at the end of the working day. This information was always integrated, and the observers usually put the length of time they spent at sea-often as long as 18 hours-as their observation time. But even during hunting trips, observations generally were not conducted steadily throughout the day, given the interruptions for actual hunting activity and the work connected with getting the harvested animals back to shore, when the observers' attention was focused on their take. For all these reasons, we considered each count from one observer-day as an observation, without regard to the duration or intensity of search. Our fundamental unit for analysis was therefore the number of seals per observation. During analysis, data were normalized to the unit (number of seals/number of observations) to provide an average for village, region, or period of time. Of the sighting data associated with each count, we used only swim direction and percentage ice cover. Both variables were assessed subjectively by the observers.

Since most villages in neighboring areas had several observers working independently of one another in the same area, we averaged the data from all the observers in each area.

Because each area had different conditions, the data from each was analyzed separately (Fig. 1):

a) Gulf of Anadyr: The coastal waters of the southern Chukotka Peninsula, including the northern part of the Gulf of Anadyr; 
TABLE 1. Timing and numbers of bearded seal observations in the coastal waters of the Chukotka Peninsula.

\begin{tabular}{lcllr}
\hline \hline Year & $\begin{array}{c}\text { Number of } \\
\text { observers }\end{array}$ & Start date & End date & $\begin{array}{c}\text { Number of } \\
\text { observations }\end{array}$ \\
\hline 1993 & 5 & 5 May & 30 November & 338 \\
1994 & 26 & 1 February & 27 December & 2616 \\
1995 & 28 & 1 February & 27 December & 4089 \\
1996 & 30 & 1 January & 20 December & 3596 \\
1998 & 9 & 1 April & 30 December & 834 \\
1999 & 19 & 1 April & 30 November & 1786 \\
2000 & 20 & 10 January & 30 December & 2290 \\
2002 & 29 & 1 March & 30 November & 3223 \\
2003 & 29 & 1 March & 28 November & 2872 \\
2004 & 9 & 1 April & 28 December & 776 \\
2005 & 20 & 1 April & 30 November & 1704 \\
2010 & 2 & 11 January & 29 November & 492 \\
2011 & 3 & 11 January & 30 December & 596 \\
2012 & 2 & 3 May & 4 December & 224 \\
\hline \hline
\end{tabular}

b) Bering Sea: The coastal waters of the eastern Chukotka Peninsula, including the extreme northwestern waters of the Bering Sea, adjacent to the Bering Strait; and

c) Chukchi Sea: The coastal waters of the northern Chukotka Peninsula, including the southwestern waters of the Chukchi Sea.

\section{RESULTS}

\section{Winter-Early Spring (January-March) Distribution}

Gulf of Anadyr: In the southern coastal waters of the Chukotka Peninsula (Gulf of Anadyr), the number of bearded seals increased from January to March. The average number of seals per observation increased from 0.4 in January to 3.5 in March (Table 2). The greatest number of individuals was observed near Nunligran. Groups of bearded seals were observed in this location every year. In March 1995, in periods of fair weather, up to 150-200 bearded seals were seen resting on the ice.

The yearly averaged counts of bearded seals in the southern coastal zone varied from 0.36 to 8.0 seals per observation. The smallest number of seals was recorded here during a mild winter in 1996, while the highest number was recorded in 2002.

Bering Sea: In the coastal zone off the eastern shore of the Chukotka Peninsula between January and March, the animals were distributed primarily on the young ice that forms on the leeward side of capes. The number of bearded seals increased from $0.4-0.5$ in January and February to 1.2 in March (Table 3). The yearly average number of bearded seals per observation off the eastern coast varied from 0.45 in 1995 to 2.4 in 2002.

Chukchi Sea: In winter, bearded seals are sometimes seen in the southern part of the Chukchi Sea. In 1995 and through the second half of January 1996 near Uelen four individuals per observation on average were observed in a large crack formed near the shore. No other observations were recorded.
TABLE 2. The average number of bearded seals observed per month in the southern coastal waters of the Chukotka Peninsula (Gulf of Anadyr) during the winter-early spring period for all years.

\begin{tabular}{lccc}
\hline \hline Parameters & January & February & March \\
\hline Number of values & 194 & 233 & 479 \\
Minimum & 0.0 & 0.0 & 0.0 \\
Maximum & 10 & 45 & 200 \\
Mean & 0.4 & 1.0 & 3.5 \\
SD & 1.3 & 4.9 & 13.4 \\
SE & 0.1 & 0.3 & 0.6 \\
Lower 95\% CI of mean & 0.2 & 0.4 & 2.3 \\
Upper 95\% CI of mean & 0.6 & 1.6 & 4.7 \\
\hline \hline
\end{tabular}

TABLE 3. The average number of bearded seals observed per month in the eastern coastal waters of the Chukotka Peninsula (Bering Sea) during winter-early spring period for all years.

\begin{tabular}{lccc}
\hline \hline Parameters & January & February & March \\
\hline Number of observations & 62 & 95 & 245 \\
Minimum & 0 & 0 & 0 \\
Maximum & 5 & 7 & 30 \\
Mean & 0.5 & 0.4 & 1.2 \\
SD & 1.2 & 1.2 & 3.0 \\
SE & 0.2 & 0.1 & 0.2 \\
Lower 95\% CI of mean & 0.2 & 0.2 & 0.9 \\
Upper 95\% CI of mean & 0.8 & 0.7 & 1.6 \\
\hline \hline
\end{tabular}

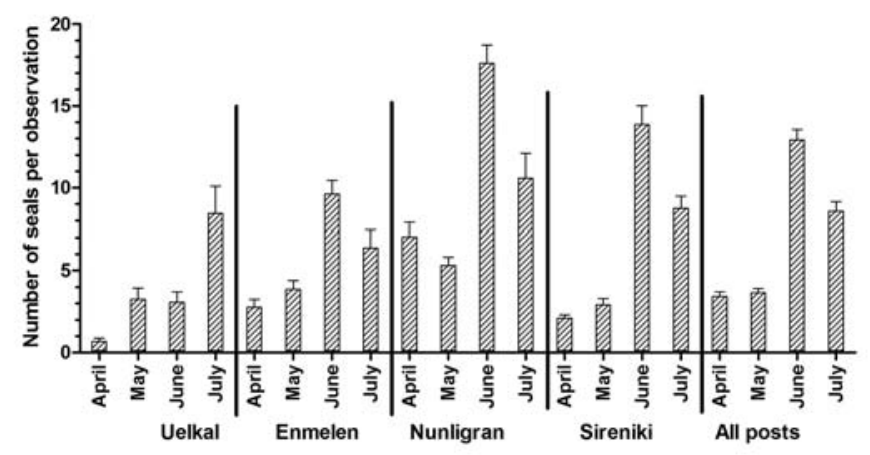

FIG. 2. Relative abundance (by month, April to July) of bearded seals recorded at four observation posts in the southern coastal waters of the Chukotka Peninsula (Gulf of Anadyr), averaged for all years of observation. Lines above columns denote the standard error.

\section{Spring and Early Summer (April-July) Distribution}

Gulf of Anadyr: During April in the southern coastal waters of Chukotka, most bearded seals aggregated near Nunligran (Figs. 2, 3a), where we recorded an average of 7.0 bearded seals per observation. The maximum number of bearded seals lying on top of the ice (120) was recorded on 22 April 2002. The lowest number of seals observed was near Uelkal (Gulf of Kresta), where in April 2002 and 2003 an average of 0.7 individuals per count was recorded. In April, $56 \%$ of all bearded seals observed were on the ice and $44 \%$ were in the water. Seals moved mainly along the coast, without any particular direction of movement, $37 \%$ 

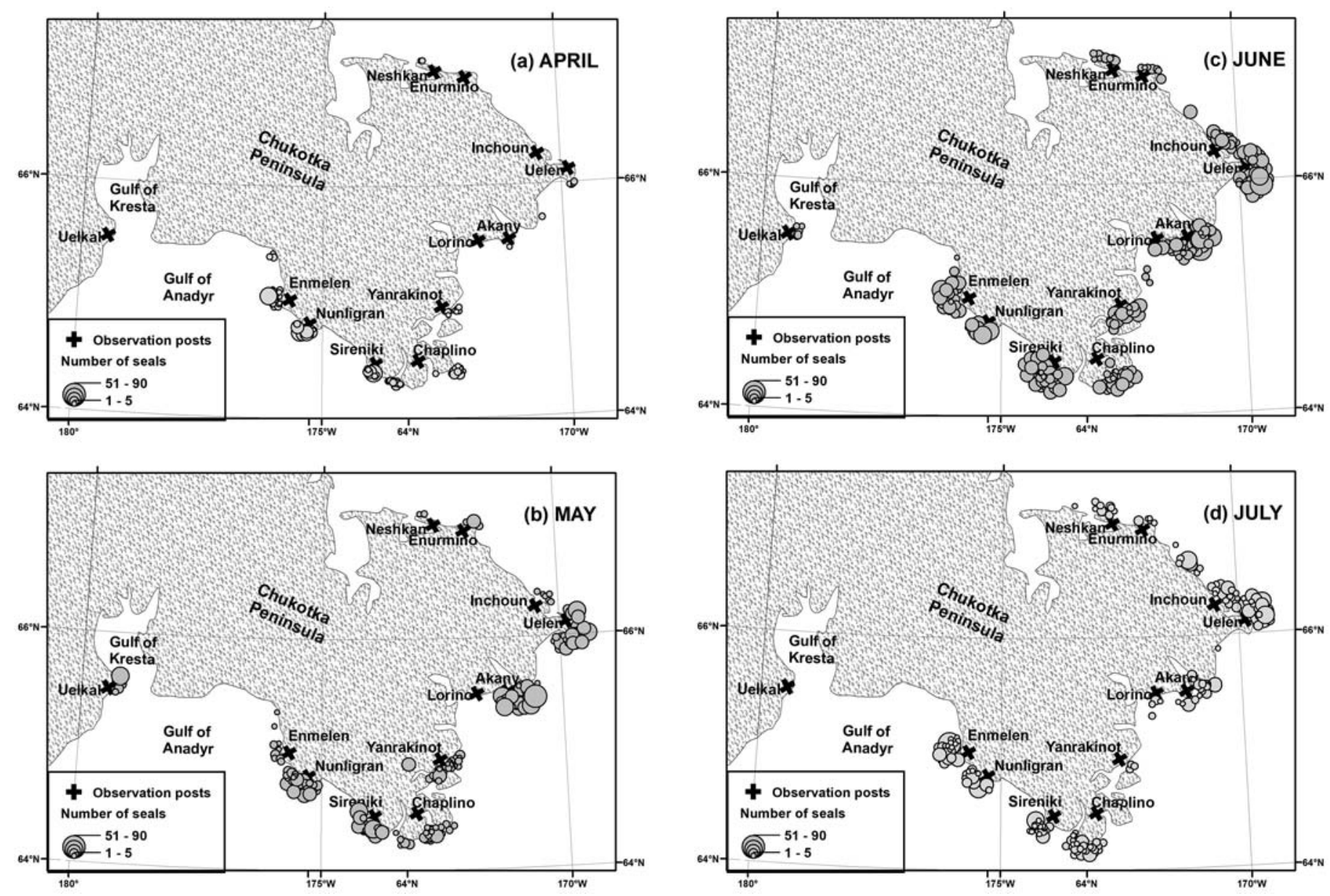

FIG. 3. Monthly distribution of bearded seals during spring migration in 1995, which was a typical year in that the highest number of observations occurred in a) April, b) May, c) June, and d) July.

were moving westward, and 33\% were moving eastward. Bearded seals drifted passively on the ice to the east.

In May, in the northwestern part of the Gulf of Anadyr, ice conditions typically become unstable and can change in a short time from solid ice cover to open water. Near Uelkal, the average number of bearded seals per observation increased from 0.7 in April to 2.7 in May. In June, numbers were similar to those in May. In the Gulf of Kresta, bearded seals were most numerous in July, when 8.4 seals per observation were recorded (Fig. 2). In general, in the northern part of the Gulf of Anadyr, the number of bearded seals observed in May remained near the level seen in April (Figs. 3, 4a, b, 5).

The highest number of bearded seals was recorded in June in all locations except Uelkal (Figs. 2, 3c, 4). Near Enmelen, up to 9.6 individuals were recorded on average, and near Nunligran the average was 17.6. Near Sireniki, at the exit of the Gulf of Anadyr, the average number of bearded seals per observation increased from 2.9 in April to 13.9 in May (Fig. 2).

By mid-July in the northern Gulf of Anadyr, the number of bearded seals observed began to decline (Figs. 2, 3d, 4). Fewer bearded seals were observed in July than in June near all villages except Uelkal. Towards the end of July in the Gulf of Anadyr, only a few bearded seals were recorded (Fig. 4).

The movement of bearded seals out of the Gulf of Anadyr began in May. Between May and July, the majority $(83 \%)$ moved to the east. On favorable days, up to 80 seals were counted swimming through open water to exit the Gulf to the east.

Bering Sea: In the eastern coastal waters of Chukotka, the average number of bearded seals per observation increased from 1.2 in March to 2.2 in April. Unlike bearded seals in the Gulf of Anadyr, those in the eastern coastal waters moved mainly to the north (73\%) and to the northeast (17\%) in April.

In May, the average number of bearded seals per observation in the eastern coastal waters increased to 4.0 (Fig. 5). In these observations, all or nearly all of the seals were moving toward the Bering Strait. In June, the number of bearded seals recorded in the eastern coastal waters increased to 6.2 seals per observation on average. In early July, the numbers of seals observed began to decrease, and by the end of that month few were observed (Fig. 6).

In this region, on average for all years, we recorded 3.5 seals per observation (range 1.2-6.9) during May to July. 

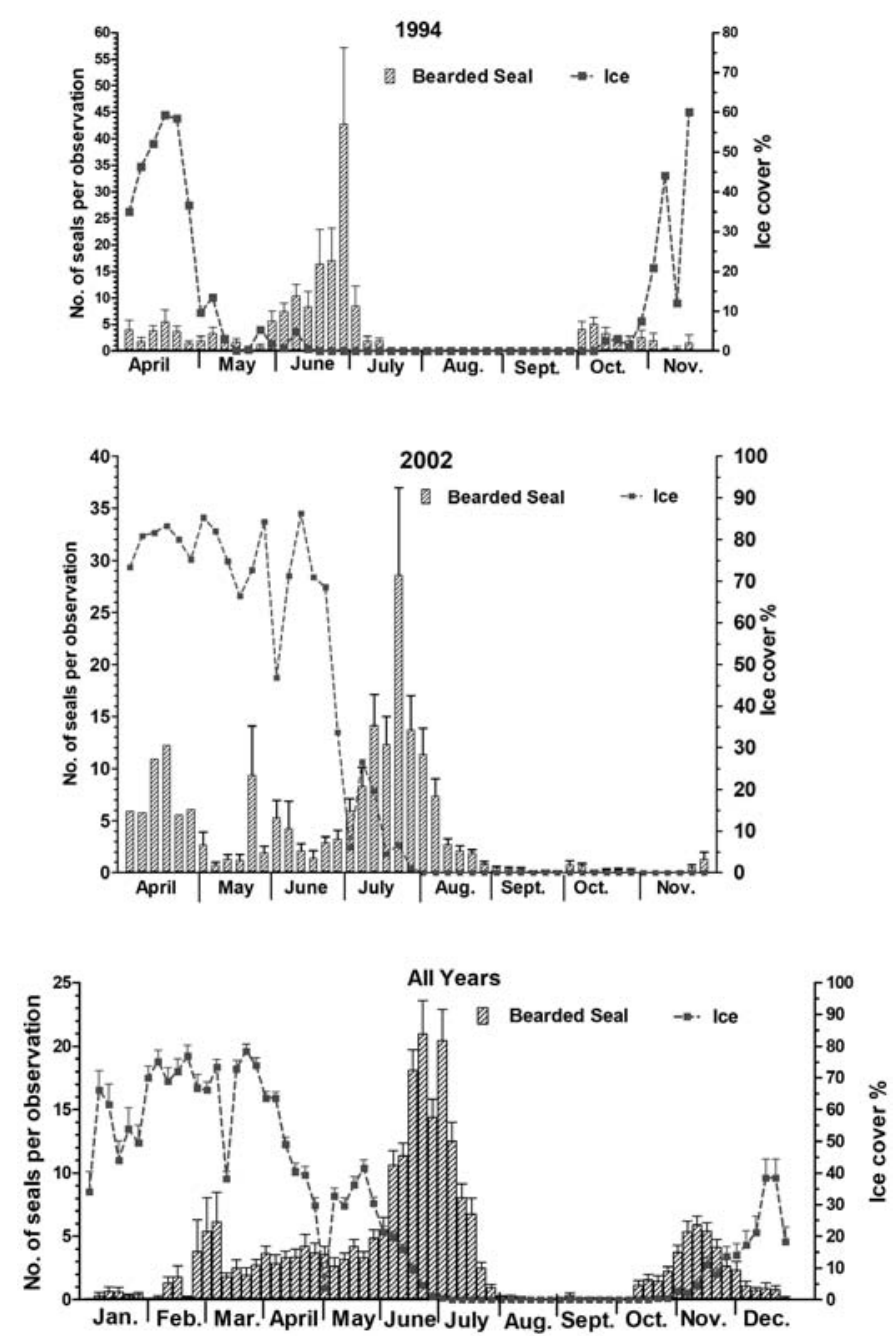

FIG. 4. Numbers of bearded seals observed in the southern coastal waters of the Chukotka Peninsula, (top) in 1994, a year with early melting and early ice formation; (middle) in 2002, a year with late melting and late ice formation; and (bottom) in all years of observation (averaged). Data were provided by observers. Each bar represents five days (or occasionally six in a longer month).

During this time period, $51 \%$ of the seals observed were on the ice.

Chukchi Sea: In early April of years with early spring (1996, 2002, and 2005), in the coastal waters of the northern Chukotka Peninsula near the villages of Uelen and Inchoun at the northwest entrance of the Bering Strait, bearded seals congregated in cracks in the flaw zone where the shorefast ice meets the pack ice. By late April, bearded seals appeared along the entire northern coast of the Chukotka Peninsula (Figs. 3a, 7, 8).

In May, the greatest number of bearded seals was observed near Uelen, where the recorded average for all years was 4.8 individuals per count (Figs. 3b, 7).

In June, about 2.5 times as many bearded seals were observed than in May. The number of individuals recorded decreased from the eastern post (Uelen) to the western post (Neshkan) (Figs. 3c, 7). The number of bearded seals recorded near Uelen was 10 times as large as the combined

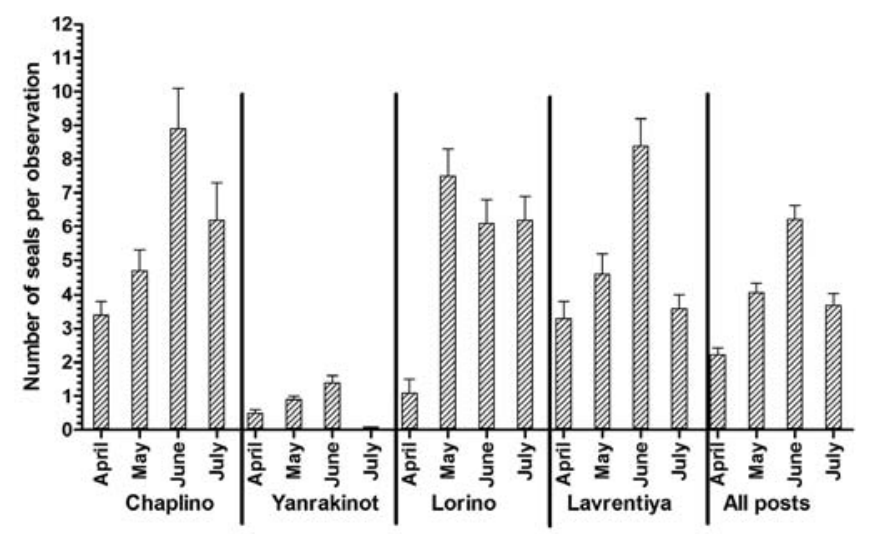

FIG. 5. Relative abundance of bearded seals at four observation posts in the eastern coastal waters (Bering Sea) in April to July, by month and observation post (average of all years). Lines above columns show the standard error.
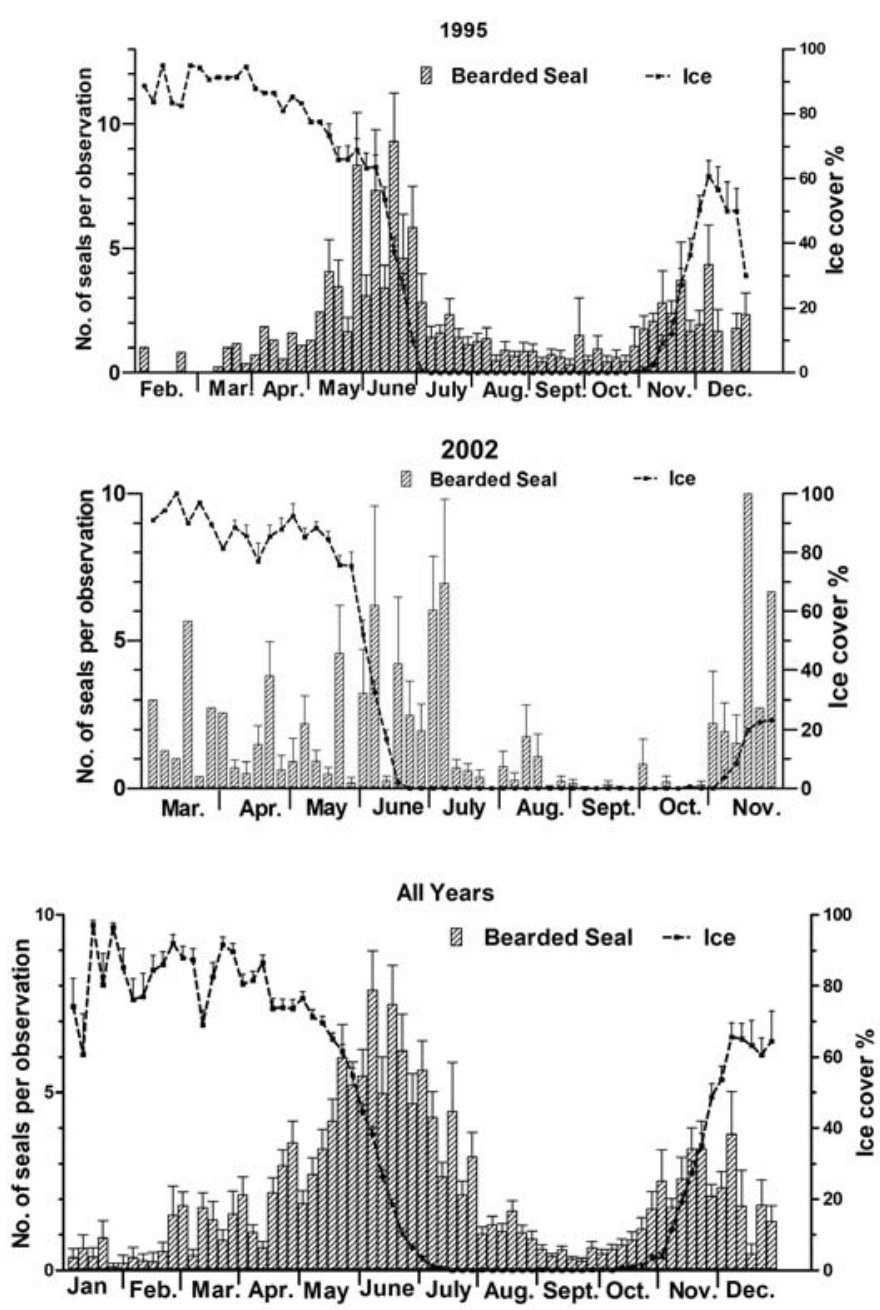

FIG. 6. Numbers of bearded seals observed in the eastern coastal waters of the Chukotka Peninsula, (top) in 1994, a year with late melting and early ice formation; (middle) in 2002, a year with early melting and late ice formation; and (bottom) in all years of observations (averaged). Data were provided by observers. Each bar represents five days (or occasionally six in a longer month).

number near Enurmino (in the vicinity of Cape SerdseKamen) and near Neshkan (at the mouth of Kolyuchinskaya 


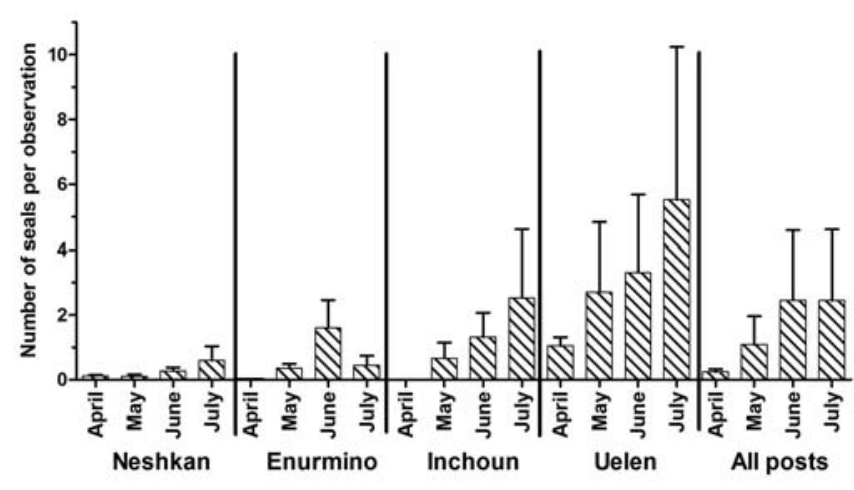

FIG. 7. Relative abundance of bearded seals at four observation posts in the northern coastal waters (Chukchi Sea) in April to July, by month and observation post (average of all years). Lines above columns show the standard error.

Bay) (Fig. 7). By the end of July, the number of bearded seals recorded in the northern coastal waters of the Chukotka Peninsula was reduced (Fig. 8).

An interannual comparison suggests a gradual increase in the mean number of bearded seals per observation from 1.0 in 1994 to 7.0 in 2000 and 2003, and a gradual decrease to 2.2 between 2003 and 2009 .

During spring in the northern coastal zone of the Chukotka Peninsula, $50 \%$ of bearded seals were moving in a northern direction and $32 \%$ were moving along the coast to the northwest.

\section{Summer-Early Autumn (August-September) Distribution}

Gulf of Anadyr: In August through September, bearded seals were rarely observed along the southern coast of the Chukotka Peninsula (Fig. 4).

Bering Sea: In the Bering Sea near the eastern coast of the Chukotka Peninsula, bearded seals were observed at low levels throughout August and September (Fig. 6). In this period observers recorded an average per day of 0.2 to 1.0 seals. No particular direction of seal movement was observed.

Chukchi Sea: In the Chukchi Sea, bearded seals were also observed at low levels in summer (Fig. 8). The greatest decrease from spring was recorded near Uelen.

\section{Autumn-Early Winter (October-December) Distribution}

During autumn and early winter, bearded seals disperse from the Chukchi Sea into the Bering Sea (Burns et al., 1981). I therefore discuss the three areas in reverse order.

Chukchi Sea: In October, across all years, only a few bearded seals were observed in the coastal waters of northern Chukotka Peninsula (Fig. 8); most (81\%) were heading southeast to the Bering Strait. During autumn, observers almost never saw bearded seals lying on the ice; most of the observations were of seals in the water. The number of bearded seals per observation remained steady from October to November, but only $30 \%$ of the
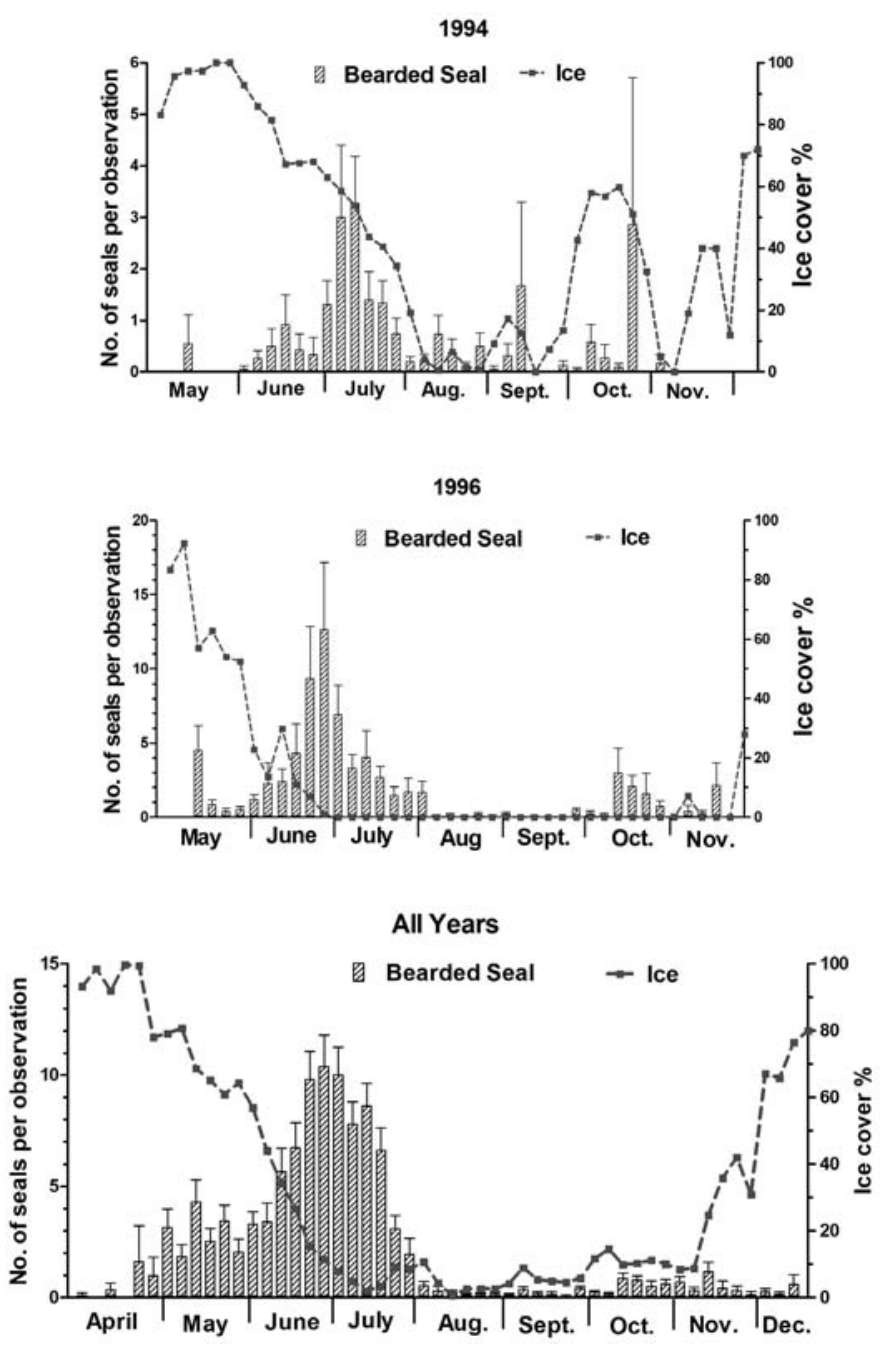

FIG. 8. Numbers of bearded seals observed in the northern coastal waters of the Chukotka Peninsula, (top) in 1994, a year with a short ice-free period; (middle) in 1996, a year with a long ice-free period; and (bottom) averaged in all years of observations. Data were provided by the observers. Each bar represents five days (or occasionally six in a longer month).

seals observed in November were moving toward the Bering Strait. In December, bearded seals were not seen in the western part of the Chukchi Sea, which is usually inaccessible for observation because of ice. At the entrance to the Bering Strait, the number of bearded seals seen per observation in December remained at the same low level as in October and November. Near Inchoun, there was a noticeable reduction in counts. Near Uelen, the number of bearded seals recorded in December remained stable.

Bering Sea: In October, with the formation of ice in the many bays on the eastern coast of the Chukotka Peninsula, bearded seal observations increased appreciably (Fig. 6). This increase was especially noticeable in Lavrentiya Bay, Mechigmen Bay, and in the bays facing toward the Senyavin Strait. In November, the number of bearded seals continued to increase in the bay areas where young ice first appeared, and 33\% of bearded seal movements were toward the south. In December the number of bearded seals remained at the same level as in November, but they did not 
exhibit any definite direction of movement, which indicates the end of the autumn migration.

Gulf of Anadyr: In most years, the number of bearded seal sightings began to increase only in the second half of October (Fig. 4). During years in which formation of ice occurred late, the number of bearded seals recorded did not increase until the end of October. At the same time, 91\% of the animals were moving in westerly and northwesterly directions, toward the northwest part of the Gulf of Anadyr. In November, the total number of bearded seals recorded in the northern Gulf of Anadyr continued to increase. The average number of individuals per observation was 4.7 seals, which was four times as high as in October; however, the seals no longer exhibited any marked direction of movement. In December, the total number of bearded seals in the northern Gulf of Anadyr decreased to around the level observed in October, suggesting that animals were only transiting this area in autumn (Fig. 4).

\section{DISCUSSION}

From the literature, little is known about the distribution of bearded seals in winter. In the Bering Sea in winter, bearded seals have been found in open water channels and in association with broken floating ice (Heptner et al., 1976; Brueggeman and Grotefendt, 1986). Bearded seals are the most widely distributed species occurring in the drifting seasonal ice of the Bering Sea (Heptner et al., 1976; Burns and Frost, 1979; Brueggeman and Grotefendt, 1986; MacIntyre et al., 2015). In most areas, they remain dispersed and do not aggregate. According to Kosygin (1966), the main aggregations occur in the areas between St. Lawrence and St. Matthew Islands, to the southeast of St. Matthew Island, and to the south of Nunivak Island. The eastern part of the Bering Sea is sparsely populated by bearded seals. Most studies consider bearded seals drifting with ice in areas with numerous polynyas, which is typical for the Bering Sea (Heptner et al., 1976).

A large-scale study conducted in 1979 and the early 1980s using helicopters transported on an icebreaker showed an extremely low number of bearded seals in the area around the ice edge (Brueggeman and Grotefendt, 1984). Low numbers were also observed in the polynyas between St. Lawrence and St. Matthew Islands and on the eastern boundary of the Gulf of Anadyr. Bearded seal density in the study area in 1979 did not exceed 0.083 individuals per $\mathrm{km}^{2}$ in the southeastern part of the basin, 0.174 in the central region, and 0.002 in the northern Bering Sea. This same density of 0.002 individuals per $\mathrm{km}^{2}$ was also recorded there in 1982 (Brueggeman and Grotefendt, 1984, 1986).

Our data show that the number of bearded seals in the northern Gulf of Anadyr gradually increases from January to March, and by late March, large aggregations form along the southern coast of the Chukotka Peninsula, mainly near Nunligran, where they haul out on the young ice that forms continually in the lee of the peninsula. The number of bearded seals in the area is highly variable, and counts can differ year to year by a factor of 12 or more. Along the eastern shore of the Chukotka Peninsula near Bering Strait, bearded seals do not form large aggregations in the winter; however, their numbers do increase from January to March too.

The literature offers very little information about bearded seals in the Chukchi Sea during the months of January to March. Aerial surveys conducted in the northeastern region of the Chukchi Sea in April in the 1980s found bearded seals there (Ljungblad, 1981; Ljungblad et al., 1983, 1986). Although bearded seals are mobile, it seems unlikely that bearded seals found in the northern Chukchi Sea $\left(72^{\circ} \mathrm{N}\right)$ in April wintered in the Bering Sea. Also, acoustic detection data indicate the year-round presence of bearded seals in the northern part of the Chukchi Sea (Hannay et al., 2013; MacIntyre et al., 2015). It is more likely that the area where polynyas occur during the winter in the northeastern Chukchi Sea (Stringer and Groves, 1991) is also winter habitat for bearded seals.

According to our data, at least some bearded seals can reproduce in the southwestern part of the Chukchi Sea, particularly in years with ample snow. Bearded seals mostly pup on top of the ice in the lee of ice hummocks, but will occasionally pup in snow lairs (Rutilevsky, 1939; Potelov, 1969). However, this practice has been observed in only a few instances. This is likely because in the western part of the Chukchi Sea, heavy ice hummocks, landfast ice, and compact drifting ice are common in winter. Young ice, which bearded seals prefer to haul out on, is absent. In addition, during the autumn ice formation, the western part of the Chukchi Sea has been dangerous even for highly adapted animals such as the bearded seal. During storms in late autumn, the sea surface is extremely cold, so with the return of calm weather the ice cover forms quickly over large areas. Moreover, as a result of the oncoming ice drift from Long Strait, which separates Wrangel Island from the Siberian mainland, and ice drifting with the action of prevailing northeasterly winds during autumn storms, pressure ridges form in the young ice, often reaching the bottom.

On the basis of our data, we can say that in April, bearded seals form aggregations in the northern part of the Gulf of Anadyr and are particularly numerous near Nunligran (Cape Achen). Bearded seals begin to leave the Gulf by May, around the time when the molting period of immature animals ends. According to Tikhomirov (1964), after molting, these animals first go to feeding areas. Later the number of migrating seals increases, reaching a peak from late June to early July. Apparently during that period, sexually mature seals leave the bay as the fast ice melts in the shallow waters at the western part of the Gulf of Anadyr. In mature bearded seals, the molting period takes place two months later than in immature individuals (Tikhomirov, 1964). Independently of whether ice melts early or late in the southern coastal waters of the Chukotka 
Peninsula, the spring migration of seals occurs at almost the same time and concludes at the end of July.

The dynamics and length of spring migration were slightly dependent on ice conditions. In years when the ice melted earlier, and in the years when it withdrew late, the main wave of migration proceeded from the middle of June to the second 10 days of July, with a peak in late June to early July. The second half of the wave occurred in open water.

In the eastern coastal waters of Chukotka in April, most seals are moving in a northerly direction. Observations indicate that bearded seals approach the east coast from the southern areas and the open part of the Bering Sea. Later, in May and June, the migration northwards along the eastern shore grows, and it peaks in late June to early July. At the end of July, the spring migration from the Gulf of Anadyr and along the eastern coast of Chukotka ceases. In typical years, the second half of the spring migration occurs in open water, after the ice cover has dissipated.

In general, the spring migration in the eastern coastal zone of the Chukotka Peninsula takes place over a longer period of time than in the Gulf of Anadyr. Beginning in April, it progresses in May to mid-July and ends in late July. As in the northern part of the Gulf of Anadyr, peak migration occurs from the end of June to the beginning of July.

In the northern coastal waters of the Chukotka Peninsula, bearded seals appear in April but are found only sporadically. In typical years, bearded seal migration activity occurs from mid-June to the end of July, with a peak in late June or early July (that is, at the same time as in the eastern and southern coastal waters). Animals move in northerly and northwesterly directions. This movement is accompanied by a consistent decline in the number of animals migrating from east to west, which indicates that bearded seals migrate along the southern and eastern shores of the Chukotka Peninsula through the Bering Strait and farther north, where floating ice is located.

Bearded seals also conduct seasonal migrations in the region of the White, Barents, and Kara Seas. They move from the southeastern Barents Sea to the east and north in the spring and summer and then travel in the opposite direction in the fall (Potelov, 1969).

In the Sea of Okhotsk, as the sea ice expands and retreats, bearded seals remain in the broken ice, inhabiting the southern edge of the pack beyond the fast ice in winter and moving north toward shore in spring and summer (Tikhomirov, 1961; Fedoseev, 1966; Heptner et al., 1976). Bearded seals are considered to be relatively sedentary over much of the rest of their range undertaking local movements in response to ice conditions and food (Cameron et al., 2010).

Very little is known about the life of bearded seals in the summer. The literature contains only a brief mention that in the western part of the Gulf of Anadyr, bearded seals are very rarely observed in summer (Kryukova et al., 2010). As this research shows, by August bearded seals have almost completely left the northern part of the Gulf of Anadyr. In the eastern coastal waters of the Chukotka Peninsula, the bearded seal population decreased in August to one-third of its July numbers; bearded seal populations are slightly greater there, but still scarce in the summer. Thus, we may assume that through August and September, the bearded seal numbers in the nearshore waters of the Chukotka Peninsula are reduced. Most likely bearded seals from the Bering Sea go to the northern part of the Chukchi Sea.

Nearshore along the Chukotka Peninsula, the autumn migration of bearded seals is minimal in both the Chukchi and the Bering Seas. Bearded seals are scattered on a broad front while migrating, not close enough for shorebased observers to detect. Bearded seals were almost never observed hauled out on the ice at this time of year.

\section{CONCLUSION}

In summary, we can conclude that the northern part of the Gulf of Anadyr is a wintering area for bearded seals. Here, the combination of wind and land maintains the formation of young ice where animals prefer to haul out. The number of bearded seals gradually increases, beginning in January. The highest concentration occurs near Nunligran (Cape Achen). Although there is high interannual variability in the numbers, this area appears to be important.

Our data support a nearshore spring migration by bearded seals from the northern part of the Gulf of Anadyr east towards the Bering Strait and then to the north. The second half of the spring migration occurs in ice-free water. By August, the eastward and northward movements of bearded seals along the coast of the Chukotka Peninsula end, and through September, the number of bearded seals seen in the coastal zone of the Chukotka Peninsula is extremely low.

Our data do not support an autumn (October-December) migration of bearded seals in the coastal zone of the Chukotka Peninsula. Bearded seals observed are moving toward the south; however, few are seen. Therefore, it appears the autumn migration occurs farther from shore and is not observable from our shore-based posts.

\section{ACKNOWLEDGEMENTS}

I extend gratitude to the North Slope Borough, Alaska, for many years of support and financial assistance to the program of research on marine mammals in the waters adjacent to the Chukotka Peninsula. I am especially grateful to Tom Albert, John "Craig" George, and all the personnel of the Department of Wildlife Management. I express gratitude to all of the observers from the communities of Chukotka, who performed the work in 1994-2012. Finally, I am greatly indebted to the reviewers as their contributions significantly improved the manuscript. 


\section{REFERENCES}

Brueggeman, J.J., and Grotefendt, R.A. 1984. Seal/sea lion and walrus surveys of the Navarin Basin, Alaska. Final Report OCSEAP, Research Unit 625. Washington, D.C.: National Oceanic and Atmospheric Administration, U.S. Department of Commerce. 94 p.

https://www.boem.gov/ESPIS/1/1051.pdf

- 1986. Seal, sea lion, walrus and beluga whale surveys of the Bering Sea, 1979 and 1982-1983. Final Report OCSEAP, Research Unit 669. Washington, D.C.: National Oceanic and Atmospheric Administration, U.S. Department of Commerce. $152 \mathrm{p}$. https://www.boem.gov/ESPIS/1/1059.pdf

Burns, J.J., and Frost, K.J. 1979. Natural history and ecology of the bearded seal, Erignathus barbatus. Final Report OCSEAP, Research Unit 230. Washington, D.C.: National Oceanic and Atmospheric Administration, U.S. Department of Commerce. $311-392$.

Burns, J.J., Shapiro, L.H., and Fay, F.H. 1981. Ice as marine mammal habitat in the Bering Sea. In: Hood, D.W., and Calder, J.A., eds. The eastern Bering Sea shelf: Oceanography and resources, Vol. 2. Seattle, Washington: National Oceanic and Atmospheric Administration, U.S. Department of Commerce. $781-797$.

Cameron, M.F., Bengtson, J.L., Boveng, P.L., Jansen, J.K., Kelly, B.P., Dahle, S.P., Logerwell, E.A., et al. 2010. Status review of the bearded seal (Erignathus barbatus). NOAA Technical Memorandum NMFS-AFSC-211. Fairbanks: NOAA, U.S. Department of Commerce. 246 p.

Fedoseev, G.A. Aerovisualniye nabludeniya sa morskimi mlekopitayschimy v Beringovom More [Aerovisual observations of marine mammals in the Bering Sea]. Izvestia TINRO 58:173-179.

Fedoseev, G.A., Raslivalov, E.V., and Bobrova, G.G. 1988. Raspredeleniye i chislennost ledovih form lastonogih na ldah Beringova morya $\mathrm{v}$ aprele i mae 1987 [Distribution and number of ice form seals on ice of the Bering Sea in April and May 1987]. In: Popov, L.A., ed. Scientific marine mammal research in the north part of the Pacific in 1986-1987. Moscow: VNIRO. 44-70.

Hannay, D.E., Delarue, J., Mouy, X., Martin, B.S., Leary, D., Oswald, J.N., and Vallarta, J. 2013. Marine mammal acoustic detections in the northeastern Chukchi Sea, September 2007-July 2011.Continental Shelf Research 67:127-146. https://doi.org/10.1016/j.csr.2013.07.009

Heptner, L.V.G., Chapskii, K.K., Arsen'ev, V.A., and Sokolov, V.T. 1976. Mlekopitayuschie Sovetskogo Soyusa [Mammals of the Soviet Union]. Vol. II, Part 3: Pinnipeds and toothed whales. Moscow: Vysshaya Shkola. 718 p.

Kosygin, G.M. 1966. Distribution of bearded seals in the Bering Sea in the spring period 1962-1964. Izvestia TINRO $58: 125-128$.
Kryukova, N.V., Pereverzev, A.A., Kochnev, A.A., and Ivanov, D.I. 2010. Marine mammals in the coastal waters of northern part of Anadyr Gulf (Bering Sea) in summer-autumn period, 2007-2008. The Researches of the Aquatic Biological Resources of Kamchatka and the North-west Part of the Pacific Ocean 19:127-132.

Ljungblad, D.K. 1981. Aerial surveys of endangered whales in the Beaufort Sea, Chukchi Sea and northern Bering Sea. Technical Document 449. Prepared for the Bureau of Land Management. AD-A 103 406. San Diego, California: Naval Ocean Systems Center.

Ljungblad, D.K., Moore, S.E., and Van Schoik, D.R. 1983. Aerial surveys of endangered whales in the northern Beaufort, eastern Chukchi, and northern Bering Seas, 1982. Technical Document 605. Prepared for Minerals Management Service, Alaska OCS Region. AD-A 134 772. San Diego, California: Naval Ocean Systems Center.

Ljungblad, D.K., Moore, S.E., Clarke, J.T., and Bennett, J.C. 1986. Aerial surveys of endangered whales in the northern Bering, eastern Chukchi, and Alaskan Beaufort Seas, 1985: With a seven year review, 1979-85. Prepared for Minerals Management Service, Alaska OCS Region. AD-A 172753. San Diego, California: Naval Ocean Systems Center.

MacIntyre, K.Q., Stafford, K.M., Conn, P.B., Laidre, K.L., and Boveng, P.L. 2015. The relationship between sea ice concentration and the spatio-temporal distribution of vocalizing bearded seals (Erignathus barbatus) in the Bering, Chukchi, and Beaufort Seas from 2008 to 2011. Progress in Oceanography 136:241-249.

https://doi.org/10.1016/j.pocean.2015.05.008

Melnikov, V.V. 2014. Kitoobrasniye (Cetacea) tihookeanskogo sektora Arktiki: Istiriya promisla, sovremennoe raspredeleniye, migracii chislennost [Whales (Cetacea) of the Pacific sector of the Arctic: History of whaling, modern distribution, migration, abundance]. Vladivostok: Dalnauka. 396 p.

Melnikov, V.V., and Bobkov, A.V. 1993. O migratsiyakh grenlandskikh kitov v Chukotskom more v 1991 g. [Migration of bowhead whales in the Chukchi Sea in 1991]. Okeanologiya 33(5):729-734.

Melnikov, V.V., Zagrebin, I.A., Zelensky, G.M., and Ainana, L.I. 2007. Killer whales (Orcinus orca) in waters adjacent to the Chukotka Peninsula, Russia. Journal of Cetacean Research and Management 9(1):53-63.

Potelov, V.A. 1969. Distribution and migrations of the bearded seal in the White, Barents and Kara Seas. In: Arseniev, V.A., Zenkovich, B.A., and Chapskii, K.K., eds. Third All-Union Conference on Marine Mammals. Moscow: Nauka. 245-250.

Rutilevsky, G.L. 1939. Promisloviye mlekopitayuschie poluostrova Cheluskin i proliva Vilkitskogo [Marine mammals of Cheluskin Peninsula and Vilkitskiy Strait]. Trudi naucho-issledovatelskogo instituta polarnogo semledeliya, zhivotnovodstva i promislovogo khosaystva, Vol. 8. Leningrad: Glavsevmorput. 7-59. 
Stringer, W.J., and Groves, J.E. 1991. Location and areal extent of polynyas in the Bering and Chukchi Seas. Arctic 44(Suppl. 1):164-171.

https://doi.org/10.14430/arctic1583
Tikhomirov, E.A. 1964. O raspredelenii I biologii lastonogih Beringova morya [On the distribution and biology of Pinnipeds in the Bering Sea]. In: Sovetskie ribohosaystvennie issledovaniya $\mathrm{v}$ severo-vostochnoy chasti Tikhogo okeana [Soviet fishery investigation in the north-east Pacific]. Moskow: Pichevaya promishlennost. 277-285. 